\title{
Obsahová analýza kurikulárních dokumentů tělesné výchovy v Nizozemsku z hlediska vybraných faktorů kvality projektovaného kurikula: komparace s RVP ZV
}

\section{The content analysis of Dutch PE projected curricula from perspective of chosen curricula factors of quality: comparison with Czech PE projected curricula}

\author{
Michal Lupač \\ Pedagogická fakulta Masarykovy univerzity, Brno
}

\begin{abstract}
Abstrakt
Školská reforma, která mimo jiné vyústila v revizi školských dokumentů, na našem území probíhá již více než deset let. Za tu dobu byla podrobena mnoha studiím, které její dosavadní výsledek hodnotí různě kriticky. Dalšívýzkum kurikula, který by mohl prispět kjeho zkvalitnění, proto považujeme za relevantní. Předkládaná studie analyzuje projektované kurikulum tělesné výchovy v Nizozemsku, které následně srovnává s projektovaným kurikulem tělesné výchovy $v$ České republice se zaměřením na vybrané faktory kvality kurikula, kterými jsou návodnost a vnitřní kongruence. Nizozemské dokumenty byly podrobeny obsahové analýze textu a následnè srovnány s českými dokumenty pomocí komparativní metody, príčemž jako výchozí vědecký prístup byla pro naši studii zvolena prípadová studie a problémový prístup s problémovými tématy vnitřní kongruence a návodnost. Výsledky studie naznačují, že vnitřní kongruence a návodnost je v nizozemských dokumentech v porovnání s českými dokumenty dosahována ve vyšší míře. V závěrečné diskusi rovněž zmiňujeme obsahovou stránku nizozemského dokumentu a vybrané rozdily s českým dokumentem.
\end{abstract}

\section{Klíčová slova}

Tělesná výchova v Nizozemsku, tělesná výchova v České republice, projektované kurikulum, komparace, vnitřní kongruence, návodnost.

\begin{abstract}
The study analyses the Dutch PE curricula documents and compares them with the Czech PE curriculum. Our research focuses mainly on the selected quality factors - internal congruence and instructional quality. The methodology is based on the qualitative (case oriented) problem approach and the comparison of the analysed documents. We present the educational content comparison of the selected curricula papers and highlight their similarities and differences. The study results indicate higher rate of the instructional quality and internal congruence of the Dutch documents compared to the Czech ones.
\end{abstract}

\section{Key words}

Physical education in the Netherlands, physical education in the Czech Republic, curriculum, comparison, internal congruence, instructional quality.

Článek vznikl za podpory projektu KUME 2015 Kurikulum základní školy: metodologické př́stupy a empirická zjištění (MUNI/A/1360/2014). Děkuji rovněž Charlotte Iványi za laskavou pomoc s překladem nizozemských dokumentů. 


\section{Úvod}

Pohyb tvoří nedílnou součást lidského života. Avšak jak naznačují některé výzkumy, v České republice klesá počet lidí, kteří se pravidelně účastní sportovních či pohybových aktivit (Eurydice, 2014, s. 8). S $35 \%$ pravidelně pohybově aktivních lidí zaostáváme v rámci Evropské unie o $7 \%$. Mezi lety 2009 a 2013 u nás vzrostl počet lidí, kteří se pohybují jen občas nebo vůbec, o $8 \%$. Klademe si proto otázku, zda jednou z prričin poklesu pohybově aktivních občanů může být způsob, jakým se náš vzdělávací systém (resp. výuka tělesné výchovy) snaži vést žáky k dlouhodobé pohybové aktivnosti.

Jednou ze zemí, které se daří počet pohybově aktivních lidí zvyšovat, je Nizozemsko. Podle studie o tělesné výchově a sportu ve školách v Evropě (Eurydice, 2013), která je podle autorů stručným pokusem o zmapování situace a poskytnutí komparativních informací ze třiceti zemí zapojených do sítě Eurydice, neposkytlo Nizozemí (spolu s Lucemburskem a Švýcarskem) pro tuto studii žádné údaje, které by mohly pozitivní nárůst pohybově aktivních lidí způsobený výukou ve školách vysvětlit. I z tohoto důvodu jsme se rozhodli zaměřit na analýzu projektovaného kurikula tělesné výchovy (TV) tohoto státu a podrobit jej komparaci s kurikulem TV v našem státě z hlediska vybraných faktorů kvality.

\section{Výzkumný problém a cíle studie}

Předkládaná studie se odkazuje a částečně navazuje na dřivější práce autorů, kteří se výzkumem projektované formy kurikula TV zabývali v zahraničí i u nás (srov. Vlček, 2009; Vlček \& Janík, 2010; Pühse \& Gerber, 2005; Richterová, 2006; Liu, 2008; Habrdlová, 2013; Lupač, 2013, 2014). Nejčastěji autoři ve svých výzkumech využivali obsahovou analýzu, kterou provedli pomocí systému témat nebo kategoriálního systému. Někteří rovněž pro rigoróznost svých prací využili postup triangulace, anebo zvolili pro sběr dat dotazníky určené zástupcům jednotlivých zemí, kteří se problematikou TV zabývali. Kromě studie Pühseho a Gerbera (2005) se autoři zabývali dvěma či maximálně třemi státy, proto tyto studie můžeme označit za případové. $V$ hledáčku zájmu autorů byla většinou obsahová stránka dokumentů a vlastní srovnání vzdělávacího obsahu TV. Některé vědecké př́stupy a metodologické postupy předkládané studie částečně vycházejí z metodologie, kterou zmínění autoři použili ve své práci.

V návaznosti na fakta zmíněná $\mathrm{v}$ úvodu této studie a pochyby ohledně úspěšnosti proběhlých reforem projektovaného kurikula, které panují napříč odbornou veřejností (srov. Janík et al., 2010b; Hrubý, 2011; Kuhn, 2011; Janík et al., 2013; Dvořák, Starý \& Urbánek, 2015 aj.), definujeme cíle naší studie. Ty vycházejí z vymezení faktorů kvality kurikula, které můžeme rozdělit do kategorií vstupů, procesů a výstupů (srov. Buhren, 2004, s. 10-11; Janík et al., 2010, s. 40; Vlček \& Mužík, 2012, s. 35). Problematika projektovaného kurikula spadá do kategorie vstupy, přičemž pro účel naší studie jsme vybrali faktory návodnost a vnitřni kongruence, které jsme se v naší studii rozhodli postihnout a ze kterých vyplývají konkrétní cíle studie.

V odborné literatuře najdeme mnoho autorů vymezujících pojem kongruence (např. Stake, 1972, s. 104-106; Egger et al., 2002, s. 44; Buhren, 2004, s. 151; s. 44; Janík et al., 2010, s. 40; Janík et al., 2011, s. 39; Vlček \& Mužík, 2012, s. 36; Janík et al., 2013, s. 32 aj.). Pedagogové se více méně shodují, že kongruence je shoda mezi projektovaným a realizovaným kurikulem. Aby tedy bylo dosaženo co nejvyšší možné míry kongruence, musí být plánované předpoklady, cíle a procesy ve shodě $\mathrm{s}$ realizovaným vzděláváním. Přidáním adjektiva vnitřní se snažíme o užší vymezení pojmu. $\mathrm{V}$ rámci naší studie proto vnitřni kongruenci vnímáme jako obsahový soulad mezi cíli, vzdělávacím obsahem (učivo a př́íp. očekávané výstupy) a standardy v projektovaném kurikulu.

Faktor kvality kurikula návodnost (instructional) považujeme za vlastnost dokumentu, která zájemci usnadňuje jeho použití v praxi. Čím více je dokument návodný, tím menší je riziko, že během realizace jeho vzdělávacího obsahu dojde k nežádoucím odchylkám. Faktor návodnost můžeme vnímat jako faktor ovlivňující kritéria kvality kurikula, $\mathrm{v}$ tomto př́padě kritéria jasnost a srozumitelnost (srov. Janík et al., 2011, s. 40). Př́lišná návodnost dokumentu (stejně jako nedostatek návodnosti) však 
může být pedagogy vnímána negativně (srov. Vollstädt et al., 1999, s. 91). Potřebu tvorby dostatečně návodných kurikulárních dokumentů zmiňuje např. Schiro (2008, s. 8).

V návaznosti na výzkumný problém definujeme cíle studie:

Cíl 1: Analyzovat obsahovou a formální stránku nizozemského projektovaného kurikula TV.

Cíl 2: Porovnat analyzované nizozemské projektované kurikulum TV s českým projektovaným kurikulem TV z hlediska vnitřní kongruence a návodnosti.

Domníváme se, že sledované faktory mohou pomoci odhalit některá úskalí našich dokumentů a věříme, že bychom $\mathrm{v}$ zahraničních dokumentech mohli nalézt inspiraci pro př́ípadné další revize národního kurikula.

Abychom dostáli principu kontextuality, jehož naplnění je jedním z předpokladů vypracování srovnávacích studií (srov. Liu, 2008, s. 26-27; Vlček, 2015, s. 401), kladou si následující odstavce za cíl čtenáře stručně seznámit se současným vzdělávacím systémem v Nizozemsku.

\section{Stručná deskripce vzdělávacího systému v Nizozemsku}

Vzdělávací systém v Nizozemsku se od českého systému školství liší v mnoha aspektech. Hlavním informačním zdrojem pro následující podkapitolu se stal evropský portál zaměřený na vzdělávání Eurydice a publikace Key Figures 2009-2013, kterou vydalo nizozemské Ministerstvo školství, kultury a vědy. Čerpali jsme rovněž ze zkušeností nasbíraných během tř́měsíčního studijního pobytu autora $v$ této zemi.

Pro děti v Nizozemsku je školní docházka povinná od pěti do šestnácti let. Do svých čtyř let mohou děti navštěvovat školky nebo jesle, které spadají pod zodpovědnost místních samospráv. Rodiče mají rovněž možnost posílat své děti do předškolních zařízení, kde je kladen větší důraz na vzdělávací aspekty. Tato zařízení jsou zaměřena na dvou až pětileté děti, u kterých hrozí rozvinutí vzdělávacích poruch (Eurydice, 2015, s. 1; Wooning, 2004, s. 62).

Primární vzdělávání v Nizozemsku trvá osm let a většina žáků jej absolvuje od čtvrtého do dvanáctého roku života na běžné základní škole pro primární vzdělávání (BAO). Děti, které mají specifické poruchy učení, výchovné problémy nebo (byt' dočasně) vyžadují asistenty nebo speciálně vybavené prostory kvůli tělesnému postižení, navštěvují speciální základní školu pro primární vzdělávání (SBAO) nebo speciální základní školu jak pro primární, tak pro sekundární vzdělávání (SO nebo VSO), které mohou navštěvovat až do svých 14. narozenin. Poté mohou pokračovat na pre-odborné vzdělávání, na školy učňovského typu nebo další běžné školy druhého stupně.

Na druhém stupni většina dětí pokračuje sekundárním vzděláváním (VO), které se větví na základní vzdělávání (HAVO), praktické vzdělávání (PRO), pre-univerzitní vzdělávání (VWO) a pre-odborné vzdělávání (VMBO). Pre-odborné vzdělávání zahrnuje další čtyři směry, kterými se žáci mohou vydat. Jsou jimi základní volitelné programy $(\mathrm{BL})$, volitelné programy pro střední management (KL), kombinované programy (GL) a teoretické programy (TL). Všechny zmíněné cesty směřují k střednímu odbornému vzdělávání (MBO). Po zvládnutí kombinovaného a teoretického programu mohou žáci rovněž jít do základního vzdělávání (HAVO), které spolu s pre-univerzitním vzděláváním (VWO) připravuje studenty na programy v rámci terciálního vzdělávání.

V rámci terciálního vzdělávání následuje odborné vzdělávání $(\mathrm{MBO})$ nebo vyšší vzdělávání (HO). MBO se dělí na odborné praktické vzdělávání (BOL) a blokové vzdělávání (BBL) a sestává ze čtyř kvalifikačních stupňů: 1. asistentská úroveň, 2. základní volitelný výcvik, 3. odborný výcvik a 4. specializovaný výcvik nebo výcvik pro střední management. Těchto stupňů mohou dosáhnout ve čtyřech sektorech: 1. personální a sociální služby a péče o zdraví, 2. inženýrství a technologie, 3. obchod a 4. zemědělství a životní prostředí, které je dotováno Ministerstvem pro hospodářské záležitosti. Vyšší vzdělávání (HO) zahrnuje vyšší profesní (HBO) a univerzitní (WO) vzdělávání.

Děti se speciálními vzdělávacími potřebami navštěvují kromě výše zmíněných běžných typů škol ještě oddělení podporující učení (LWOO), speciální sekundární školy (VSO) nebo praktické vzdělávání (PRO). Dospělí mohou navštěvovat kurzy pro dospělé. V následujícím diagramu je zobrazena struktura nizozemského vzdělávacího systému (Missler \& Groeneveld, 2014). 


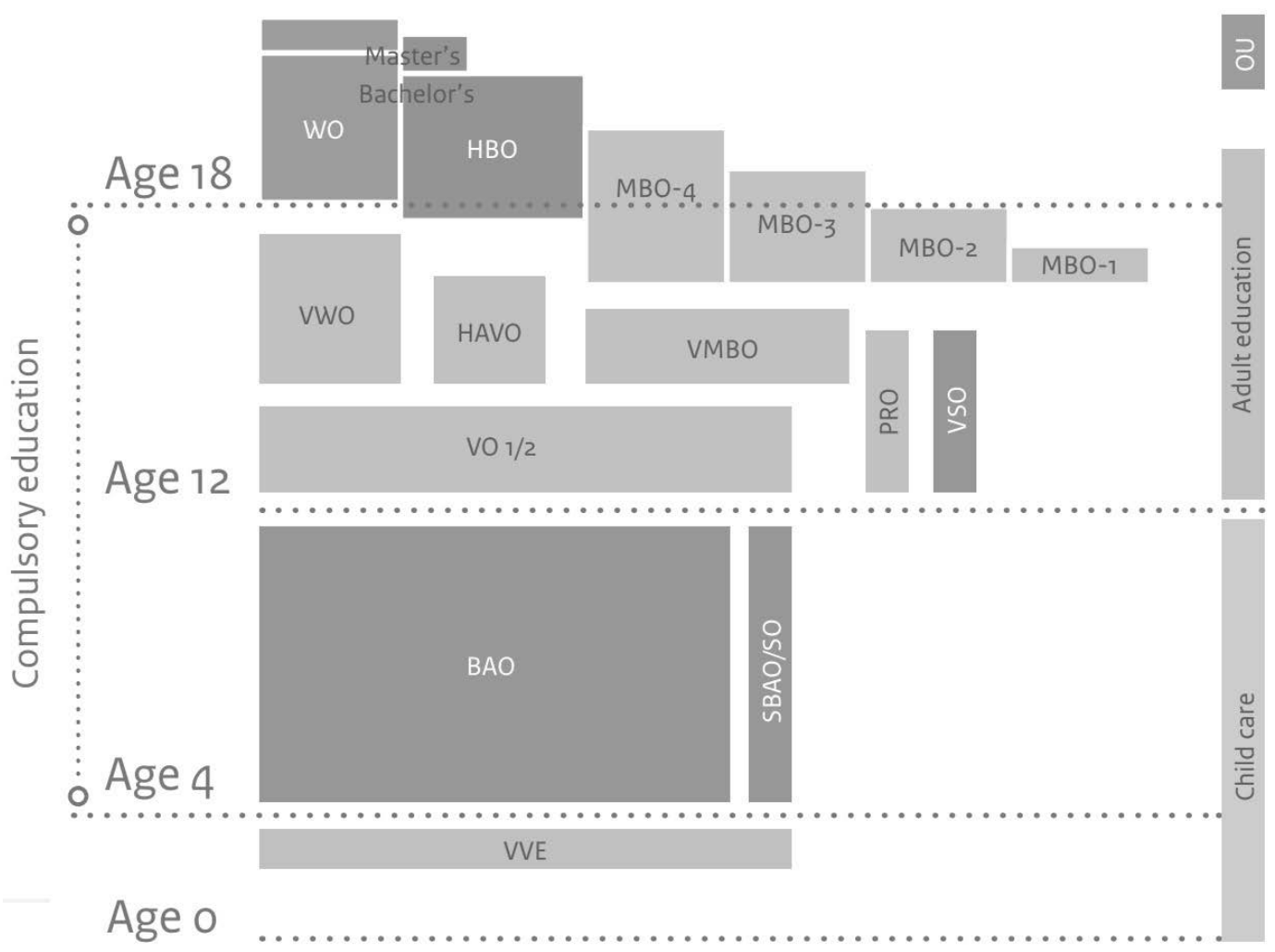

Prostupnost mezi jednotlivými typy škol znázorňuje následující diagram (Missler \& Groeneveld, 2014, s. 8). Čísla u jednotlivých šipek uvádějí transfer žáků v procentech.

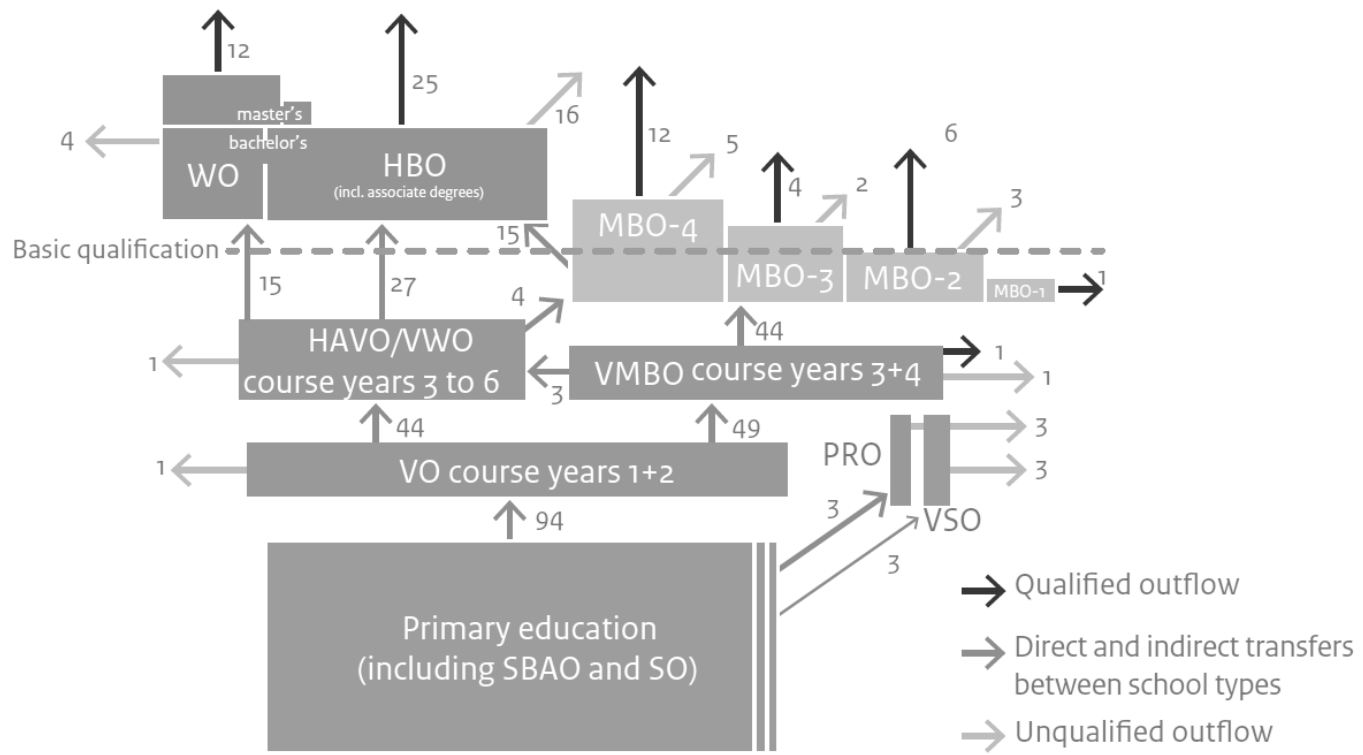

Jak je patrné z uvedeného textu, systém vzdělávání v Nizozemsku se v mnohém podobá českému systému, ačkoliv mezi oběma systémy existuje i několik rozdílů. Patrně nejdůležitější odlišností je 
v kontextu naší studie fakt, že základní vzdělávání na úrovni ISCED 1 začíná v Nizozemsku dříve a končí později než u nás, což se promítá i do sledovaných kurikulárních dokumentů.

\section{Analýza projektovaného kurikula tělesné výchovy}

V následující části pojednáme o zkoumaných dokumentech a použité metodě, pomocí které jsme dokumenty analyzovali.

\section{1) Použité metodologické postupy}

Výzkumný design naší práce vychází z konceptu případové studie a problémového přístupu (srov. Vlček, 2015, 2016, v tisku). Hendl (2005, s. 104) uvádí, že př́padová studie je empirický výzkumný design, jehož smyslem je „velmi podrobné zkoumání a porozumění jednomu nebo několika málu prrípadů.“ (srov. Švaříček, Šed’ová et al., 2007, s. 97). Jak se shodují někteří autoři, hodnotná komparativní studie musí být prováděna s předem jasně definovaným problémem (Holmes, 1981, s. 61; 1991, s. 25; Gavora, 2010, s. 182). Jak uvádí Vlček (2015, s. 403; 2016, v tisku), snahou badatele je v tomto úvodním kroku definovat výzkumné pole, ve kterém problém existuje. Noah a Eckstein (1969, s. 127, in Vlček, 2015, s. 403) uvádějí, že zásadní výhodou stanovení výzkumného problému jako východiska pro další výzkum je možnost výběru dat, která jsou pro daný výzkum relevantní. Jako problémová témata jsme zvolili faktory návodnost a vnitřní kongruence (viz výše). Domníváme se, že zvolený výzkumný design odpovídá charakteru a formě zkoumaného jevu, kterým jsou kurikulární dokumenty.

Základním výzkumným souborem pro analýzu kurikulárních dokumentů TV v Nizozemsku se staly dokumenty z primárních zdrojů, které spolu úzce souvisí a které nemohou být chápány odděleně. Zkoumanými dokumenty jsou:

- Kerndoelen Primair Onderwijs - Klíčové cíle pro primární a nižší sekundární vzdělávání (National Institute for Curriculum Development, 2006);

- Basisdocument Bewegingsonderwijs voor het Basisonderwijs - Základní dokument TV pro základní vzdělávání (National Institute for Curriculum Development, 2011).

Oba dokumenty jsou vydány Národním institutem pro kurikulární vývoj (SLO) a zahrnují úroveň prvního stupně základní školy (ISCED 1), která je v hledáčku našeho zájmu. Pro upřesnění dodejme, že dokument Kličové cile pro primární a nižši sekundárni základní vzdělávání (dále jen Klíčové cíle) je pro školy závazný, zatímco dokument Základni dokument tělesné výchovy pro základní vzděláváni (dále jen Základní dokument) nikoliv.

Jako základní výzkumná metoda studie byla zvolena obsahová analýza písemných dokumentů, která byla provedena nekvantitativním způsobem (srov. Gavora, 2010, s. 142). Tento způsob cílí na zjištování obsahu sdělení slov či větších slovních a větných celků, nikoliv primárně na jejich kvantifikaci v rámci kategorií, ačkoliv jak uvádí Váňová (1998, s. 64), ke kvantifikaci může dojít i v kvalitativním výzkumu. Obsah obou dokumentů jsme analyzovali pomocí formálních charakteristik a systému témat, který prochází neustálým vývojem.

Dokumenty byly jednotlivě studovány a „rozbity“ na dílčí významové jednotky, které byly shlukovány do jednotlivých kategorií. Z hlediska pedagogické a kinantropologické terminologie však bylo obtížné tyto kategorie korektně pojmenovat, proto byly slučovány a přetvářeny do témat. Tato témata slouží k obsahové deskripci dokumentů a usnadňují systematizaci získaných dat (Hendl, 2005, s. 211). Můžeme tedy říci, že témata vznikala induktivně prostřednictvím metody otevřeného kódování (srov. Strauss \& Corbinová, 1999, s. 42-52; Hendl, 2005, s. 211; Švaříček \& Šed’ová, 2007, s. 211-222 aj.). Některá témata (srov. Lupač, 2014, s. 20-21) byla přejata deduktivní metodou z prací, které se již dř́ve analýzami projektovaného kurikula TV zabývaly (Richterová, 2006; Vlček, 2009; Vlček \& Janík, 2010; Habrdlová, 2013; Lupač, 2014). Obsahová vymezení témat byla během 
studia dokumentů nadále precizována ${ }^{1}$. Systém témat ${ }^{2} \mathrm{v}$ aktuální podobě obsahuje následující témata: problematika pohybových her v TV, problematika sportovních her $\mathrm{v} T \mathrm{TV}$, problematika zdraví v TV, problematika fyzické zdatnosti v TV, rozvoj celoživotní pohybové aktivnosti, hodnocení kvalitativních změn v TV, problematika znalostí v TV a problematika časové dotace v TV.

Prostřednictvím témat je popsána obsahová dimenze dokumentů, na jejímž základě byla zjišt’ována jejich návodnost, zatím co na základě struktury dokumentů byla posuzována jejich vnitřní kongruence. Abychom mohli posouzení vnitřní kongruence provést rigorózním způsobem, rozhodli jsme se oprít o strukturu českého RVP ZV $(2013)^{3}$ a zkoumané dokumenty jsme proto sledovali v linii cíle $=>$ obsah (učivo a očekávané výstupy) $=>$ standardy $^{4}$. Ve výsledkové části upozorňujeme, zda dokumenty danou linii drží (a zda je obsahově sourodá) či nikoliv. Jak uvádí Janík a kol. (2011, s. 41), ,jednou z možností, jak usuzovat na kvalitu kurikulárního dokumentu, je porovnat ho s jiným kurikulárním dokumentem." Naše práce proto nemá ambici vyjádřit míry vnitřní kongruence a návodnosti v číslech, nýbrž v porovnání s jinými kurikulárními dokumenty.

\section{Výsledky}

Následující řádky si kladou za cíl seznámit čtenáře s výsledky analýzy dokumentů a jejich komparace s českými dokumenty v rámci zmíněných problémových témat. Nejprve je věnována pozornost formálním charakteristikám, kterými jsou formát dokumentu, grafika dokumentu, jeho začlenění v rámci širšího kurikula, struktura a rozsah (srov. Lupač, 2013, s. 58; 2014, s. 30), a následně jsou dokumenty popsány po obsahové stránce. Porovnání nizozemských dokumentů s českým RVP ZV a určení jejich návodnosti a vnitřní kongruence uvádíme v závěru podkapitoly.

\section{Formální charakteristiky dokumentů}

Naše studie popisuje a analyzuje dva dokumenty. Jak uvádíme v části Stručná deskripce vzdělávacího systému $v$ Nizozemsku, děti navštěvují školu již od čtyř let a primární vzdělávání trvá přibližně do dvanácti let. Proto oba dokumenty, ačkoliv jsou určeny pro první stupeň základní školy, pokrývají alespoň částečně rovněž úrovně ISCED 0 a 2.

Závazný dokument Kličové cile byl vydán nizozemským Ministerstvem školství, kultury a vědy v roce 2006. Dokument obsahuje krátký úvod, který souhrnně popisuje účel dokumentu, a následně krátké charakteristiky obecných cílů všech oblastí vzdělávání, které jsou obsahem nizozemského vzdělávání. U charakteristiky každého předmětu jsou následně jmenovány klíčové cíle, které jsou očíslované . Dokument má celkem 73 stran, svým grafickým zpracováním připomíná brožuru a na webových stránkách SLO je dostupný rovněž v anglickém jazyce ${ }^{6}$.

Charakteristika předmětu tělesná výchova (Bewegingsonderwijs) zaujímá v dokumentu šest stran, avšak vzhledem ke grafickému zpracování je část pojednávající o TV velmi stručná (na necelé dvě strany). V rámci systému předmětů je TV zařazena až na poslední místo a zahrnuje pouze dva klí-

1 Pro bližší seznámení s dosavadním vývojem systému témat se odkazujeme na dřívější práce autora (Lupač, 2013, 2014). V těchto pracích se hovoří o kategoriálním systému, avšak jsme si vědomi jeho limitů v oblasti požadavků kladených na parametry kategoriálních systémů, proto jej nadále použiváme jako nástroj pro systematizování dat na obecnější úrovni systému témat.

2 Původní systém témat vznikal na základě analýzy RVP ZV. Proto je v části Výsledky zmíněno téma Problematika fyzické zdatnosti v TV, ačkoliv v případě nizozemských dokumentů zůstalo nenaplněno. Naopak během analýzy vniklo nové téma Problematika časové dotace v TV.

3 Míněn vzdělávací obor Tělesná výchova vzdělávací oblasti Člověk a zdraví.

${ }^{4}$ Standardy nejsou součástí RVP ZV, nicméně patři do systému platných kurikulárních dokumentů pro základní vzdělávání v ČR. Uved’me rovněž, že standardy pro obor TV jsou nezávazné.

5 V celém dokumentu jde o 58 klíčových cílů pro všech sedm vyučovacích předmětů.

6 Přesná adresa je http://www.slo.nl/primair/kerndoelen/Kerndoelen_English_version.doc. Tato verze dokumentu je ovšem graficky zpracována jinak. Nevyznačuje se žádnými speciālními grafickými zvláštnostmi a pưsobí jako strohý text. Rovněž je spojena s charakteristikami a klíčovými cíli předmětů pro sekundární vzdělávání. 
čové cíle, které jsou označeny čísly 57 a 58 . Pro srovnání: předmět holandština jich má 12 , prvouka (personal and world orientation) jich má 20 , výtvarná výchova trri. V některých dalších předmětech jsou klíčové cíle navíc dále strukturovány do oblastí?

Protože klíčové cíle pro TV začínají vazbou „Žáci se nauči“ (The pupils learn to...), můžeme část dokumentu určenou pro TV označit za orientovanou na žáka (outcome based).

Druhým dokumentem, který jsme podrobili našemu zkoumání, je nezávazný Základní dokument, který byl vydán SLO poprvé v roce 2004. Dále byl aktualizován přibližně v ročních až dvouletých intervalech. Aktuální (a námi studovaná) verze pochází z roku 2011 a stejně jako všechny předchozí je napsána v nizozemštině. Dokument je tištěn na křídovém papíře a vydáván ve formě knihy v tvrdých deskách. Nadpisy a některé odstavce jsou vyvedeny modrou barvou. Dokument je oproti závaznému dokumentu popsanému výše mnohem obsáhlejší (432 stran) a rovněž více strukturovaný. $Z$ hlediska struktury se dokument věnuje postupně následujícím kapitolám:

1. Pojetí TV v základním vzdělávání (4 strany);

2. Učební linie $^{8}$ a mezicíle (10 stran);

3. Řízení činností v TV (7 stran);

4. Učební plán (12 stran);

5. Úloha učitele (6 stran);

6. Př́íklady (cca 380 stran);

7. Doporučený seznam základních pomůcek.

Vzhledem ke struktuře RVP ZV můžeme říci, že v systému nizozemských dokumentů rovněž nalézáme linii cíle (dokument Klićové cíle) $=>$ učivo (část Učební plán a Př́klady) $=>$ standardy (mezicíle). Jak se tedy ukazuje, nizozemský systém kurikulárních dokumentů nepracuje s očekávanými výstupy - ty jsou významově sloučeny se standardy. To, do jaké míry jsou zmíněné části obsahově sourodé, popisujeme v následující části studie.

\section{Obsahová stránka analyzovaných dokumentů}

Na následujících stránkách nejprve popíšeme dokument Klíčové cíle a poté rozebereme Základní dokument. Vzhledem k rozsahu dokumentů proběhne způsob analýzy pomocí systému témat pouze u Základního dokumentu, u nějž zmíníme i obsahové vymezení jeho kapitol.

V části o TV, která v dokumentu Klíčové cíle zaujímá poměrně málo místa, najdeme krátkou charakteristiku vzdělávací oblasti (Karakteristiek) a dva hlavní cíle TV (Kerndoelen bewegingsonderwijs), které jsou vyústěním zmíněné charakteristiky. Z konkrétního učiva jsou v úvodní charakteristice uvedeny pouze pohybové činnosti balancování, skákání, lezení, houpání, kotouly, běhání a pohyb na hudbu; dále dokument zmiňuje honičky, brankové hry ${ }^{9}$, házecí hry ${ }^{10}$, žonglování ${ }^{11}$ a úpolové hry, které souhrnně označuje jako sporty a hry. První klíčový cíl je zaměřen zejména na snahu docílit trvalého zapojení žákủ do celoživotní pohybové aktivnosti (bewegingscultuur) ${ }^{12}$. Toho má

\footnotetext{
7 Např. v př́ípadě již zmíněné prvouky se jedná o oblasti společenská studia, příroda a technologie, prostor (zemĕpis) a čas (dějepis).

8 Protože jsou v textu učební linie zmíněny vícekrát, uved'me jejich seznam již nyní. Jsou jimi: balancování, šplhání, houpání, kotouly, skákání, běhání, házení na cíl, žonglování, míčové hry, honičky, úpolové hry a pohyb na hudbu.

9 V originále slovo mikken, které holandsky znamená mírit, avšak $\mathrm{v}$ anglické verzi dokumentu je přeloženo jako goal games.

${ }^{10} \mathrm{~V}$ originále doelspelen, což bychom volněji přeložili jako hry, ve kterých jde o odrážení nebo házení předmětů na co největší vzdálenost nebo přsesnost.

${ }^{11}$ Nejde o žonglování v pravém slova smyslu. Ačkoliv z popisovaného dokumentu nemůžeme vyčíst, co konkrétně se tím myslí, z druhého analyzovaného dokumentu vyplývá, že jde především o různé formy manipulace s předměty - házení předmětu tak, aby jej bylo možné chytit, udržet předmět t'ukavým pohybem ve vzduchu apod.

${ }^{12}$ Uved'me rovněž anglický překlad pojmu exercise culture, který poukazuje na problém možné desinterpretace některých pojmů způsobené jejich nepřesným překladem. Ačkoliv bychom snadno mohli pojem
} 
být dosaženo prostřednictvím naučení se hlavním principům nejdůležitějších sportů a forem cvičení. Druhý klíčový cíl klade důraz na účast na pohybových aktivitách s ostatními žáky, a to s respektem, v souladu s domluvenými pravidly a s přihlédnutím k vlastním pohybovým možnostem.

Druhým dokumentem, na který jsme se zaměřili, je mnohem obsáhlejší Základni dokument. Ten velmi zevrubně rozvádí to, co je nastíněno v dokumentu Klíčové cíle v části pojednávající o TV. Vedle toho, že je v knize začleněn i závazný dokument, ve kterém jsou uvedeny dva hlavní cíle, můžeme tyto cíle nalézt i v samotném textu.

V kapitole Pojetí TV v základním vzdělávání je např́klad uvedeno, že „Cílem TV je dosáhnout u žáků celoživotní pohybové aktivnosti.“ (SLO, 2011, s. 11). V části Plánování v souvislosti s hlavními pohybovými problémy se uvádí, že je nezbytné, aby si ,žáci zažili a naučili se realizovat reprezentativní pohybové činnosti vhodné pro školní věk." (SLO, 2011, s. 11). Tato úvodní kapitola rovněž uvádí, že obsahem výuky jsou mezicíle, které jsou vypracovány pro všechny učební linie a věkové skupiny. Tyto mezicíle slouží mj. k evaluaci žáků v rámci konkrétní aktivity, kterou žák aktuálně provádí. Dokument se zabývá také pozicí TV v systému ostatních školních předmětů. Obsah této části ale spíše obhajuje, proč by měla školní TV zůstat jedním ze základních vyučovacích předmětů: škola je místo, kde se pohybové cíle nejlépe realizují, protože „skrze školu jsou ovlivněny všechny děti a ve škole může být po dobu mnoha let sledován jejich vývoj.“ (SLO, 2011, s. 12). Dokument rovněž uvádí, že použivání metod explorativního a spolupracujícího vyučování zabraňuje vzájemnému srovnávání žáků a jejich vyčerpání, čímž upozorňuje na sociální význam pohybu. Text dokumentu dále říká, že je důležitý intenzivní kontakt mezi školou a dalšími skupinami (zejména sportovními kluby), protože další pohyb má přispívat k vedení dětí k celoživotní pohybové aktivnosti, a proto není izolace ve škole ideální. Část úvodu nazvaná Evaluace tělovýchovných učebních situací uvádí čtenáře do problematiky, pravidel a zásad hodnocení žáků. Např́íklad zmiňuje, že naučit se vidět souvislosti je důležitější než naučit se standardním řešením ${ }^{13}$. Dokument zdůrazňuje hodnotu těchto principů, které vyvyšuje nad zvládnutí specifických pohybových činností.

V kapitole Učební linie a mezicíle je uvedena přehledná tabulka všech učebních linií, jejich pohybových témat a pohybových problémů. Tabulka 1 ukazuje jejich vzájemnou hierarchii na př́kladu učební linie skákání.

Tabulka č. 1: Vzájemná hierarchie učebních linií, pohybových témat a pohybových problémů.

\begin{tabular}{|l|l|l|}
\hline Uč. linie & Pohybové téma & Pohybový problém \\
\hline Skákání & Volné skoky & Odrazit se k dlouho trvajícímu skoku \\
\cline { 2 - 3 } & Skoky s podporou & $\begin{array}{l}\text { Odrazit se k dlouho trvajíímu skoku před anebo po umístění } \\
\text { rukou na podpưrnou plochu }\end{array}$ \\
\cline { 2 - 3 } & Skoky v kontinuálním pohybu & Umět v běhu překonat překážku \\
\cline { 2 - 3 } & Skoky přes švihadlo & Odrážet se pro opakované skákání přes točící se lano \\
\cline { 2 - 3 } & Skok do dálky a výšky & Odrazit se pro překonání co největší výšky nebo dálky \\
\hline
\end{tabular}

Autoři dokumentu se v této kapitole rovněž zabývají charakteristikou klíčových aktivit, které jsou rozděleny do čtyř věkových skupin. V kapitole je dopodrobna vysvětleno, jaké aspekty musí klíčová aktivita splňovat, aby plnila svou roli. Jako nejdůležitější je zmíněna charakteristika zvládnutelnosti alespoň $90 \%$ dětí musí aktivitu zvládnout, aby ji učitel mohl považovat za účelnou. Vedle klíčových aktivit se dokument zabývá i vedlejšími aktivitami a uvádí některé jejich př́íklady. Například v učební linii balancování může být vedlejší aktivitou k chůzi po stabilní ploše chůze po „slackline“ kousek

bewegingscultuur přeložit jako pohybová kultura, v kinantropologické terminologii tento pojem odpovídá jinému vymezení, než jak jej chápou sledované dokumenty. $Z$ jejich kontextu vyplývá, že je pojmem exercise culture míněna celoživotni pohybová aktivnost, proto se tohoto překladu budeme nadále držet.

${ }^{13}$ Jako př́ílad je uvedeno, že „Žáci musí vědět, že uvolnit se ve fotbale se principiálně neliší od uvolnění se v basketbale." (SLO, 2011, s. 13). 
nad zemí. Kapitola se též zabývá modifikacemi aktivit a jejich třemi způsoby provedení. Aktivitu je podle autorů dokumentu možno modifikovat pomocí změny rozestavění pomůcek, pomocí změny provedení aktivity (např. při skoku dopad do dřepu místo do stoje), nebo pomocí změny v řízení žáků. V dokumentu jsou pohybové situace uspořádány do učebních linií, kterými jsou balancování, šplhání, houpání, kotouly, skákání, běhání, házení na cíl, žonglování, míčové hry, honičky, úpolové hry a pohyb na hudbu. Učební linii tvoří na sebe navazující mezicíle v okruhu podobných pohybových situací pro různé věkové kategorie a vedle nich také př́slušná pohybová témata a hlavní aktivity, které jsou zvoleny tak, aby se žáci naučili adekvátně vyřešit pohybové problémy. Mezicíle jsou v dokumentu rozděleny do různých úrovní podle míry participace žáků na činnostech, od elementárních po komplexnější (např. princip bránění přihrávky v míčových sportech). Seřazení těchto úrovní se používá jako princip uspořádání pro po sobě následující učební situace, ze kterých se vytváří metodická řada.

Sledovaný dokument se rovněž velmi podrobně zabývá tzv. Řízením činností $v T V$. Citujme $\mathrm{z}$ dokumentu:

„Aby se mohli žáci správně účastnit celoživotní pohybové aktivnosti, je důležité, aby věděli, že existují podmínky a pravidla pohybových situací, které jsou proměnné a spoluurčují kvalitu pohybových aktivit. Proto se musí naučit, jak mohou aplikovat jednoduché změny. Žáci se také musí naučit udržet aktivitu v chodu. Musí umět zacházet s problémy, které se mohou objevit.“ (SLO, 2011, s. 11-12).

V této kapitole je rozlišeno celkem devět pravidel, pomocí kterých může učitel ř́́dit míru a způsob participace žáků na průběhu hodiny. Tyto úrovně jsou u každého pravidla čtyři a v dokumentu jsou popsány i s prŕíklady. Jak autoři uvádí, cílem učitele by mělo být každému žákovi přidělit takovou roli na řízení společné aktivity, aby ji byl schopen zodpovědně naplnit.

Kapitola pojednávající o Učebním plánu poukazuje na krajní podmínky při jeho sestavování a jak s nimi pracovat. Těmito podmínkami jsou např. čas, který má učitel během roku k dispozici (více viz níže téma Problematika časové dotace v TV), různá vývojová stadia dětí, která je předurčují k rozvoji určitých schopností a dovedností, vybavenost tělocvičen apod. Kapitola je zakončena tabulkou, která nabízí jasné průběžné mezicíle, které by děti měly zvládnout v určitém věku. To, jak tabulka vypadá, pro přehlednost ukazuje popis učební linie balancování. 


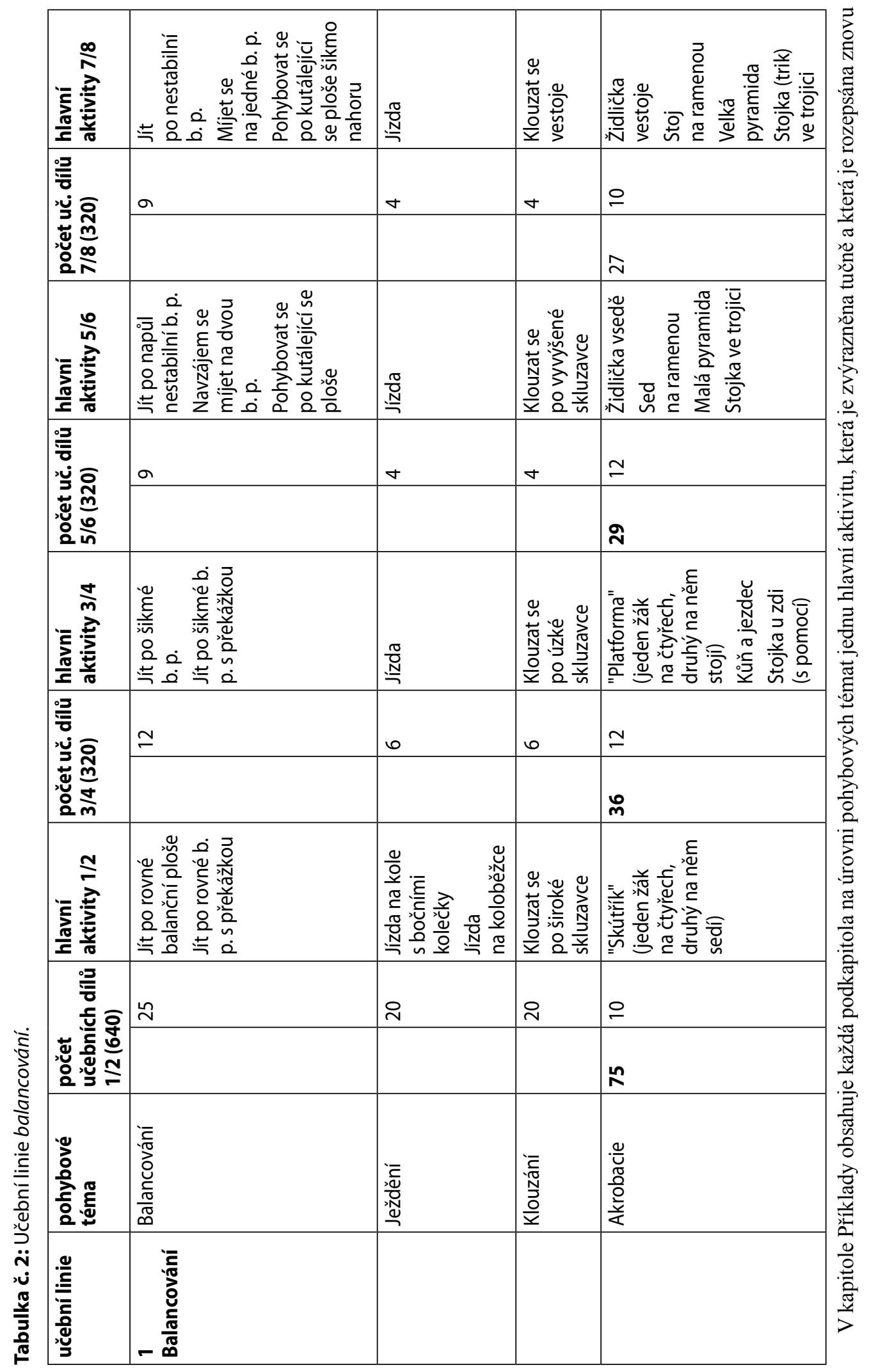


a ještě podrobněji, než ostatní aktivity (cca na 6 stran). Strukturou těchto aktivit se zabývá kapitola dokumentu Úloha učitele. Každá taková aktivita obsahuje následující části:

- popis aktivity;

- způsob zahájení aktivity;

- mezicíle a dopomoc učitele;

- regulace aktivit dětmi;

- navazující a vedlejší aktivity.

Kapitola Přiklady tvoří zásobník konkrétních příkladů a námětů, které učitelé mohou využít $\mathrm{k}$ dosažení jednotlivých cílů a mezicílů. Kapitola je rozdělena na 12 podkapitol podle učebních linií. Každá podkapitola obsahuje úvod, ve kterém je napsáno, proč je daná učební linie v knize zařazena, dále hlavní znaky aktivit a pohybová témata s pohybovými problémy. Následně je podkapitola rozčleněna na pohybová témata. $V$ rámci každé podkapitoly na úrovni pohybových témat je nejprve uveden pohybový problém, dále hlavní aktivity pro jednotlivé věkové skupiny (jedna z nich vždy tučně; viz výše), vedlejší aktivity pro každou věkovou skupinu a výčet rozšiřujících faktorů ${ }^{14}$. Následují popisy hlavních aktivit a výčet mezicílů pro každou věkovou skupinu (tedy čtyř úrovní, kterých žáci mohou dosáhnout). Součástí každé aktivity je navíc výčet pomůcek, jasně zadaný úkol aktivity, černobílý kreslený obrázek, kde je aktivita zobrazena a regulační cíle (ty vycházejí z kap. Řízení činností v TV). Př́klad struktury aktivit ukazuje obrázek 3.

Mezicíle
$\begin{array}{ll}\text { Skupina } 1 / 2 & \text { Jít po rovné balanční ploše } \\ \text { Hlavní aktivita } & \begin{array}{l}\text { Kladina (10 cm široká, } 20 \mathrm{~cm} \\ \text { vysoká), např́. dva metry dlouhá } \\ \text { otočená lavička } \\ \text { "Chůze po délce lavičky na druhou } \\ \text { stranu" }\end{array} \\ \text { Úkol }\end{array}$
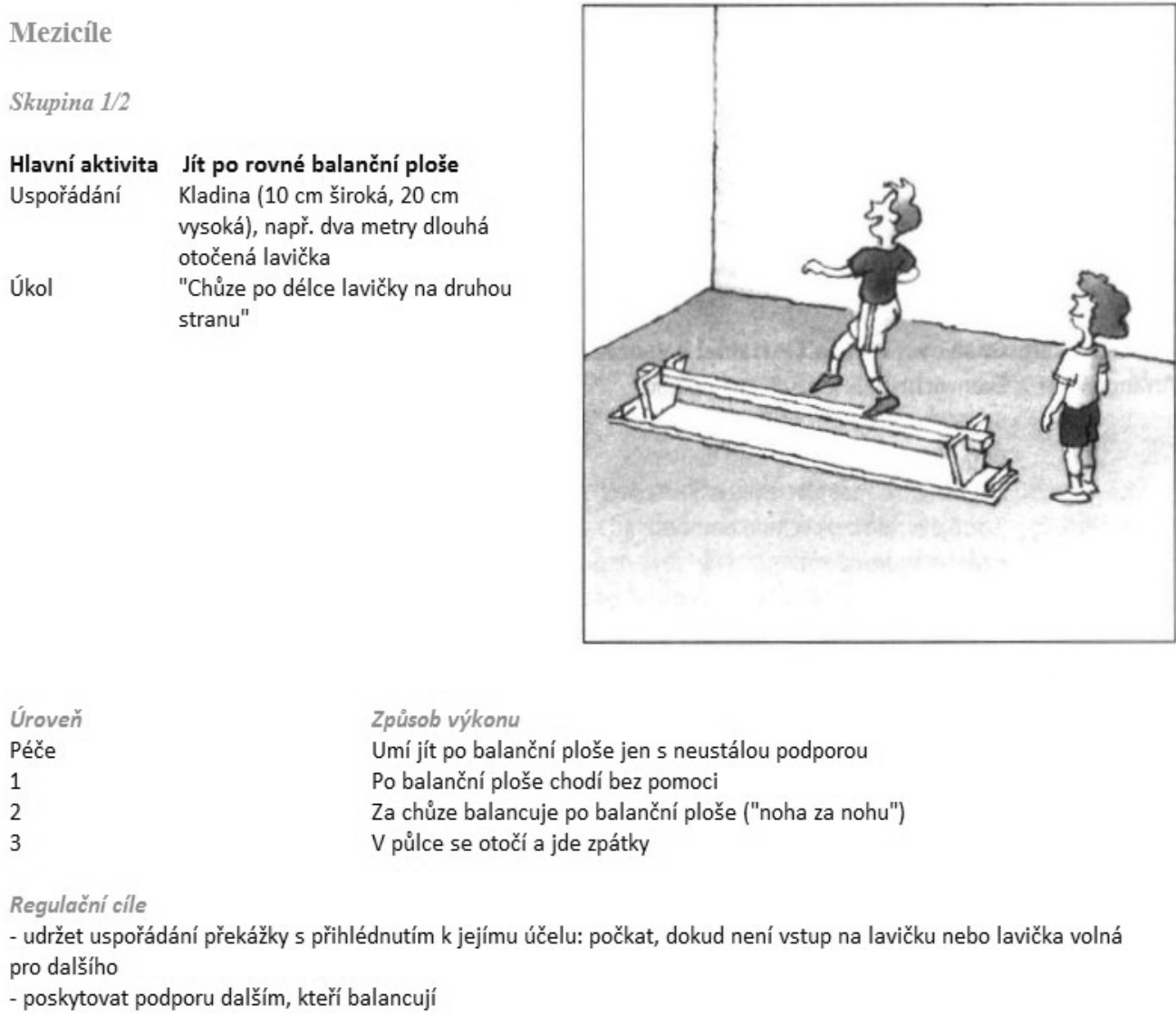

Výše uvedený popis jednotlivých kapitol slouží pro ilustraci míry návodnosti. Nyní uvedeme analýzu

${ }^{14} \mathrm{U}$ pohybového tématu balancováni jsou rozšiřujícími faktory např. přechod z široké lavičky na úzkou, z krátké na dlouhou apod. Více viz kapitola dokumentu 2.5 Rỉzné modifikace. 
pomocí témat, která nám umožní odhalit nejen obsah, kterým učitelé hodiny TV naplňují, ale rovněž obsahový soulad mezi cíli a učivem. Průběh tvorby systému témat zmiňujeme v části Použitá metodologie.

(1) Problematika pohybových her v TV

Studovaný dokument ve většině učebních linií nenabízí samotné pohybové hry, ale mnoho pohybových činností, které pro ně mohou sloužit jako východisko. Příkladem je např. učební linie honičky ${ }^{15}$, v rámci které jsou rozlišena tři pohybová témata: honičky, odrážecí hry a pálkovací hry. Pohybové hry jsou pritom zmíněny pouze v pohybovém tématu honičky.

(2) Problematika sportovních her v TV

Sportovní hry v TV jsou v dokumentu pokryty několika učebními liniemi. V rámci linie míčové hry dokument rozlišuje tři pohybová témata: střelbu, kličkování a kombinaci střelby a kličkování. Úkolem žáků je vyzkoušet si a naučit se různé způsoby překonání brankáře, který brání náš cíl, nebo obehrát soupeře, který se jim snaži míč sebrat, nebo kombinace výše zmíněných činností. Prostřednictvím učební linie honičky a jejích pohybových témat odrážeci a pálkovaci hry dokument nabízí další hry, jako je např. vybíjená. $\mathrm{V}$ dokumentu jsou zmíněny i některé hry, které jsou modifikované a využívají herních dovedností ze známějších sportovních her. Těmito hrami jsou např. cricketbal, hakobal nebo pilonbal ${ }^{16}$.

(3) Problematika zdraví v TV

Dokument př́mo o zdraví pojednává jen ve velmi omezeném rozsahu. Hned v úvodu zmiňuje, že „sport v důležité míře přispívá zdraví obyvatelstva.“ (SLO, 2011, s. 11). Explicitně o zdraví se dokument již nikde dál nezmiňuje. Můžeme ovšem nalézt místa, kde autoři dokumentu zmiňují bezpečnost. Zásadně o ní pojednává kapitola, která se věnuje řízení činností. Je na učiteli, aby zvolil vhodnou participaci žáků na přípravě a průběhu aktivit tak, aby byla aktivita bezpečná (i když zvolí maximální míru participace, zůstává odpovědnost za bezpečnost na něm).

(4) Problematika fyzické zdatnosti v TV

Toto téma není v dokumentu žádným způsobem zastoupeno (viz výše).

(5) Rozvoj celoživotní pohybové aktivnosti

Téma celoživotní pohybové aktivnosti je důležitou složkou první části dokumentu, která pojednává o pojetí TV. Autoři dokumentu zdůrazňují nutnost vedení žákủ k pohybově aktivnímu životnímu stylu, což je klíčovým cílem celé TV.

(6) Problematika psychosociální výchovy v TV

Autoři dokumentu kladou důraz na to, aby se žáci vzájemně nesrovnávali. Výchova ve smyslu spolupráce, pochopení potřeb a možností druhých směřuje k naplnění cíle dosažení pohybově aktivního životního stylu s respektem k ostatním. $Z$ hlediska sociální výchovy dokument poukazuje na význam pohybu v sociálním životě a TV chápe jako prostředek pro sebeurčení. Dokument přímo říká, že „,cítit se doma v pohybových situacích je spoluurčující pro důležité sociální vztahy, v rámci kterých jsou děti vnímány svým okolím.“(SLO, 2011, s. 12).

(7) Hodnocení kvalitativních změn v TV

Dokument disponuje velmi jasným, srozumitelným a podrobným manuálem pro zjištování pokroku dětí. Systém hodnocení postavený na mezicílech dovoluje učiteli sledovat i velmi malé pokroky, které žák učinil, a to u všech aktivit zmíněných v části Přiklady. To, jakým způsobem jsou v učebních liniích podle obtížnosti uspořádány jednotlivé mezicíle, proto slouží jako základ pro evaluaci. Míra zlepšení skupiny nebo žáků se tedy vyjadřuje podle úrovně, ve které se žáci mohou účastnit daného typu pohybové situace. Jak dokument dále zmiňuje, na základě učebních linií a mezicílů je vytvořen digitální systém pro sledování rozvoje žákủ, který se nazývá Beleyes a díky kterému mohou být

${ }^{15}$ V originále tikspelen. Tik znamená plácnutí, klepnutí nebo cvaknutí, spelen znamená hra. Upozorňujeme, že pod názvem honičky dokument zmiňuje poněkud širší škálu her, než jaká se v českém prostředí pod tímto termínem obvykle skrývá.

${ }^{16}$ Zájemce o bližší popis těchto her odkazujeme na samotný dokument (SLO, 2011, s. 320-321, 362-364). 
žáci během celé své školní docházky sledováni (a tedy i hodnoceni) ve svém pohybovém vývoji. $\mathrm{Z}$ dokumentu dále vyplývá, že učitel by neměl klást důraz na vzájemné hodnocení žáků.

(8) Problematika znalostí v TV

Žáci by podle dokumentu měli být vedeni k získávání znalostí v oblasti pravidel sportovních i pohybových her a dále v oblasti taktických individuálních i skupinových činností (např. princip obrany nebo útoku). Dokument též zdůrazňuje, že hodnota znalostí těchto principů by měla být vyvyšována nad hodnotu praktických dovedností. Autoři dokumentu také hovoří o potřebě znalosti teorie pohybu, aby jej žáci uměli aplikovat při naplňování svých pohybových potřeb. Znalosti se po žácích (i když nepřímo) vyžadují rovněž při řízení činností. Dokument předpokládá, že žáci musí vědět a umět, jakým způsobem poskytnout svým spolužákům dopomoc, jakým způsobem nachystat aktivitu nebo jakým způsobem modifikovat činnost tak, aby i nadále byla pro žáky srozumitelná, zábavná, a aby se jich mohlo na činnosti podílet co nejvíce. To úzce souvisí s participací na pohybově aktivním životním stylu, které by se podle dokumentu měli žáci naučit v různých rolích ${ }^{17}$ (SLO, 2011, s. 11).

(9) Problematika časové dotace v TV

Dokument se rozvržení času věnuje velmi podrobně v kapitole Učební plán. Časovému rozvržení aktivit (nejen kdy, ale také jak dlouho) přikládají autoři velkou roli, což se projevilo v tabulce shrnující hlavní aktivity a doporučení, co dělat v různých věkových skupinách. Tyto skupiny se označují $1 / 2,3 / 4,5 / 6$ a 7/8, přičemž skupina $1 / 2$ odpovídá věku 4-5 let, tedy vzdělávání na úrovni ISCED 0. Dokument vychází z předpokladu, že skupina $1 / 2$ má ve svém rozvrhu 4 hodiny $\mathrm{TV}^{18}$ týdně, zatímco skupiny 3/4, 5/6 a 7/8 mají dvě hodiny týdně. Dokument každou hodinu rozděluje na čtyři více méně stejně díly. Těchto dílů je tedy pro první věkovou skupinu během roku k dispozici 640, pro ostatní věkové skupiny 320 . Autoři s těmito díly dopodrobna pracují u každé klíčové aktivity, jak ukazuje tabulka 2, a dokument rovněž obsahuje přehlednou tabulku s doporučenou procentuální distribucí času jednotlivým učebním liniím (tabulka 3), kterou uvádíme níže.

Tabulka č. 3: Doporučená procentuální distribuce času jednotlivým učebním liniím.

\begin{tabular}{|l|c|c|c|c|}
\hline Učební linie & Skupina 1/2 & Skupina 3/4 & Skupina 5/6 & Skupina 7/8 \\
\hline Balancování & $12 \%$ & $11 \%$ & $9 \%$ & $8 \%$ \\
\hline Šplhání & $8 \%$ & $5 \%$ & $4 \%$ & $4 \%$ \\
\hline Houpání & $5 \%$ & $8 \%$ & $7 \%$ & $7 \%$ \\
\hline Kotouly & $3 \%$ & $3 \%$ & $3 \%$ & $3 \%$ \\
\hline Skákání & $11 \%$ & $11 \%$ & $14 \%$ & $13 \%$ \\
\hline Běhání & $0 \%$ & $3 \%$ & $3 \%$ & $3 \%$ \\
\hline Házení na cíl & $7 \%$ & $10 \%$ & $12 \%$ & $11 \%$ \\
\hline Žonglování & $9 \%$ & $8 \%$ & $6 \%$ & $6 \%$ \\
\hline Míčové hry & $3 \%$ & $6 \%$ & $10 \%$ & $14 \%$ \\
\hline Honičky & $9 \%$ & $13 \%$ & $12 \%$ & $12 \%$ \\
\hline Úpolové hry & $2 \%$ & $3 \%$ & $3 \%$ & $3 \%$ \\
\hline Pohyb na hudbu & $9 \%$ & $9 \%$ & $8 \%$ & $8 \%$ \\
\hline $\begin{array}{l}\text { Ztráty při } \\
\text { zaokrouhlení }\end{array}$ & $22 \%$ & $10 \%$ & $9 \%$ & $8 \%$ \\
\hline
\end{tabular}

Ztráty jsou dány zaokrouhlením procentuálních dotací jednotlivým liniím a uvádíme je přímo $\mathrm{z}$ dokumentu, ač si jsme vědomi jejich matematicky nelogických hodnot.

${ }_{17}$ Tím je myšleno nejen to, zda žák hraje v obraně nebo v útoku, ale rovněž to, zda zrovna neplní funkci časomíry nebo počitadla apod.

${ }^{18} \mathrm{~V}$ tomto věku se do TV zahrnuje i pobyt venku. 


\section{Komparace nizozemských dokumentů s RVP ZV}

Srovnání formálních charakteristik nizozemských kurikulárních dokumentů TV s Rámcovým vzdělávacím programem pro základní vzdělávání ${ }^{19}$ přehledně shrnuje tabulka 4.

Tabulka č. 4: Srovnání formálních charakteristik dokumentů.

\begin{tabular}{|c|c|c|c|c|}
\hline $\begin{array}{l}\text { Formální } \\
\text { charakteristiky }\end{array}$ & RVP ZV (Z) & Standardy (N) & Klíčové cíle (Z) & $\begin{array}{l}\text { Základní } \\
\text { dokument (N) }\end{array}$ \\
\hline Formát & $\begin{array}{l}\text { Elektronický } \\
\text { dokument }\end{array}$ & \begin{tabular}{|l} 
Elektronický \\
dokument
\end{tabular} & Brožura & Kniha \\
\hline Rozsah & $4 / 142$ & $16 / 36$ & $\begin{array}{l}6(\mathrm{z} \text { toho } 2 \text { strany } \\
\text { textu)/73 }\end{array}$ & $432 / 432$ \\
\hline Grafika & \begin{tabular}{|l|} 
Volný text, \\
očekávané výstupy \\
v tabulce, učivo \\
v odrážkách
\end{tabular} & $\begin{array}{l}\text { Text v tabulkách, } \\
2 \text { obrázky (jeden } \\
\text { barevný, jeden } \\
\text { šedý) }\end{array}$ & $\begin{array}{l}\text { Volný text, klíčové } \\
\text { cíle očíslovány } \\
\text { v bodech } \\
\text { a na fialovém } \\
\text { pozadí }\end{array}$ & $\begin{array}{l}\text { Volný text, tabulky } \\
\text { s učebními liniemi } \\
\text { a učebním plánem, } \\
\text { černobílé obrázky } \\
\text { u příkladů }\end{array}$ \\
\hline Začlenění & $\begin{array}{l}\text { TV jako vzdělávací } \\
\text { obor vzdělávací } \\
\text { oblasti Člověk } \\
\text { a zdraví } \\
\end{array}$ & \begin{tabular}{|l|} 
Samostatný \\
dokument pro TV, \\
nezačleněn
\end{tabular} & $\begin{array}{l}\text { TV jako jeden } \\
\text { z předmětů } \\
\text { kurikula }\end{array}$ & $\begin{array}{l}\text { Samostatná } \\
\text { kniha pro TV, } \\
\text { nezačleněno }\end{array}$ \\
\hline Struktura & \begin{tabular}{|l|} 
- Volný text \\
charakterizující \\
vzdělávací \\
oblast Člověk \\
a zdraví (TV \\
v samostatných \\
odstavcích) \\
- Cíle oblasti \\
- Očekávané \\
výstupy pro 1. a 2. \\
období \\
- Učivo - činnosti \\
ovlivňující \\
zdraví, úroveň \\
pohybových \\
dovedností \\
a podporující \\
pohybové učení
\end{tabular} & \begin{tabular}{|l} 
- Volný text \\
sloužící jako \\
klíč pro použití \\
dokumentu \\
- Tabulky \\
obsahujíí \\
indikátory \\
(standardy) \\
pro očekávané \\
výstupy pro 2. \\
období \\
\end{tabular} & $\begin{array}{l}\text { - Volný text } \\
\text { charakterizující } \\
\text { TV jako vyučovací } \\
\text { předmět } \\
\text { - Očíslované } \\
\text { klíčové cíle TV }\end{array}$ & \begin{tabular}{|l} 
- 55 stran \\
rozdělených \\
na kapitoly \\
popisující pojetí \\
TV, učební linie \\
a mezicíle, řízení \\
činností v TV, \\
učební plán \\
a úlohu učitele \\
- 377 stran \\
s prýklady činností \\
vTV \\
- 1 strana \\
s doporučeným \\
seznamem \\
pomůcek \\
pro vybavení \\
tělocvičny
\end{tabular} \\
\hline
\end{tabular}

U každého dokumentu pro přehlednost uvádíme, zda je závazný $(Z)$ nebo nezávazný $(\mathrm{N})$. Upozorňujeme, že názvy jednotlivých dokumentů byly v tabulce z úsporných důvodů zkráceny. U charakteristiky rozsah je uveden počet stran věnujících se oboru TV na úrovni ISCED 1 z celkového počtu stran dokumentu.

V porovnání s RVP ZV jsou v dokumentu Klíčové cíle uvedeny cíle, ale nenajdeme téměř žádné učivo, očekávané výstupy nebo standardy. Jak jsme zmínili v analýze obsahu dokumentů, dokument obsahuje výčet učebních linií, ale ty nejsou nijak dále rozvedeny.

Základni dokument zahrnuje cíle, které vycházejí z dokumentu Klíčové cíle, dále učivo, které je vyjádřeno formou několika tabulek a velmi rozsáhlou kapitolou Př́klady. Kniha rovněž obsahuje

${ }^{19}$ Dokumentem RVP ZV je míněna část o vzdělávací oblasti Člověk a zdraví, obor Tělesná výchova. 
standardy, které jsou však nazvány mezicíle. Jak zmiňujeme výše, nizozemský systém kurikulárních dokumentů nepracuje s očekávanými výstupy, které jsou významově sloučeny se standardy, resp. mezicíli. Ty jsou tvořeny hlavními aktivitami, pro které jsou vypracovány vždy čtyři úrovně ${ }^{20}$, na kterých mohou žáci aktivitu zvládnout. V porovnání s RVP ZV je tedy patrné, že nizozemské dokumenty disponují propracovanějším systémem standardů, který je zaměřen na všechny věkové skupiny a který je víceúrovňový z hlediska zvládnutí/nezvládnutí pohybové aktivity. Tento systém standardů je stejně jako v České republice nezávazný.

Z analýzy obsahové dimenze dokumentů vyplývá, že prostřednictvím popsaného vzdělávacího obsahu je možné naplnit cíle TV v Nizozemsku a to i přes jejich široké vymezení. Nahlížíme-li na oba nizozemské dokumenty jako na ucelený systém, najdeme jasnou obsahově sourodou linii mezi cíli, vzdělávacím obsahem a standardy, ačkoliv z hlediska struktury nizozemské dokumenty nepracují s pojmem očekávané výstupy, který je významově sloučen se standardy (resp. mezicíli). Vzdělávací obsah je v Základním dokumentu velmi podrobně popsán a definován, nechybí rozvržení časové dotace jednotlivým činnostem ani postupy, které mohou učitelé ve své výuce využívat pro její zefektivnění. Základni dokument proto tvoří ucelenou a logicky systematizovanou podrobnou př́ručku, pomocí které mohou učitelé snáze naplnit obsah hodin TV, řídit jejich průběh a evaluovat úroveň schopností a dovedností žáků.

Vzdělávací oblast RVP ZV Člověk a zdraví nabízí charakteristiku oblasti a dále cíle, které jsou zaměřeny především na zdraví2 ${ }^{21}$. Z dokumentu ovšem nevyplývá, zda mají být naplněny prostřednictvím vzdělávacího oboru Výchova ke zdraví nebo Tělesná výchova. Vzdělávací obsah oboru Tělesná výchova je pak kompilátem očekávaných výstupů a učiva, které ovšem z větší části nemají př́mou souvislost $\mathrm{s}$ cíli uvedenými v dokumentu. V porovnání se Základním dokumentem můžeme konstatovat, že český dokument se nijak nevěnuje dalším činnostem učitele, jako je plánování a př́prava hodiny TV či způsoby ř́zení samotných aktivit během TV. Dokument nezmiňuje způsoby, jakými se mohou žáci zapojit do př́prav či kontroly jednotlivých aktivit, evaluaci žáků, pravidla pro vymýšlení smysluplných a vhodných aktivit atp. RVP ZV působí spíše jako seznam okruhů činností a očekávaných výstupů, se kterými může učitel naložit různým způsobem, a v rámci kterých může hledat konkrétní činnosti.

Domníváme se, že z výše uvedených důvodů dosahují analyzované dokumenty v porovnání s českými dokumenty vyšší míry vnitřní kongruence a návodnosti. Vyšší míru kongruence v nizozemských dokumentech spatřujeme $\mathrm{v}$ obsahovém souladu na strukturální linii cíle $=>$ vzdělávací obsah $=>$ standardy. Vyšší míra vnitřní kongruence rovněž zvyšuje i přehlednost a srozumitelnost dokumentu. Vyšší návodnost je patrná z propracovanosti Základního dokumentu, jak dokládají výsledky analýzy formálních charakteristik a obsahové dimenze dokumentu.

\section{Shrnutí a diskuse}

Předkládaná stat' si klade za cíl prrispět do diskuse o kvalitě kurikula. Identifikuje kritéria návodnost a vnitřní kongruence jako faktory kvality kurikula, v rámci kterých porovnává české a nizozemské projektované kurikulum TV.

$\mathrm{Z}$ analýzy vyplynulo, že české projektované kurikulum dosahuje v porovnání se sledovanými nizozemskými dokumenty nižší míry vnitřní kongruence a návodnosti. $Z$ hlediska obsahové dimenze dokument RVP ZV předkládá různé skupiny pohybových činnostín ${ }^{22}$, které dále nespecifikuje a je proto na učitelích, jakým způsobem je do své výuky zařadí. Ještě úspornějším způsobem přistupuje

${ }^{20} \mathrm{Na}$ úroveň péče, na které žák aktivitu de facto nezvládne, by mělo připadat $10 \%$ dětí. Na zbylé tři (očíslované) úrovně by mělo dosáhnout postupně $90 \%, 50 \%$ a 20\% žáků (od nejnižší úrovně po nejvyšší).

${ }^{21} \mathrm{Z}$ devíti cílů jsou jen dva, kde zdraví není zmíněno. Tyto cíle hovoří o poznávání člověka jako jedince a dále o chápání zdatnosti, dobrého vzhledu a duševní pohody jako předpokladu pro výběr profesní dráhy, partnerů, společenských činností apod.

${ }^{22}$ Např. cvičení s náčiním, využití hraček a netradičního náčiní při cvičení, ale i organizace a bezpečnost cvičebního prostoru, chůze v terénu, měření výkonů aj. (RVP ZV, 2013, s. 79). 
k závaznému vzdělávacímu obsahu nizozemský dokument Klíčové cíle, který zmiňuje pouze dvanáct učebních linií a sám o sobě je nijak dále nerozvádí. Je proto opět na učitelích, jakým způsobem s nabízeným učivem naloží. Ze zmíněných faktů usuzujeme, že české i nizozemské projektované kurikulum TV nabízí pedagogům relativní volnost ve výběru konkrétního vzdělávacího obsahu, která je však u nás o něco menší. V obou príípadech ovšem platí, že realizace vzdělávacího obsahu by měla být podmíněna vzdělávacími cíli, které jsou v dokumentech definovány, a učitelé by se jimi ve své výuce TV měli ř́́dit.

Zde narážíme na zásadní rozdíl mezi českým a nizozemským projektovaným kurikulem TV. Upozorňujeme na fakt, že výhradně zdravotně zaměřené cíle vzdělávací oblasti Člověk a zdraví není možné prostř̌ednictvím některých nabízených činností naplnit. $Z$ hlediska cílů se totiž pojetí TV v České republice jeví jako zdravotní (srov. Naul, 2003; RVP ZV, 2013, s. 75), avšak jak upozorñují někteří autoři (Vlček \& Mužík, 2012, s. 40) a potvrzuje to i naše studie, vzdělávací obsah inklinuje spíše k pohybovému pojetí23. Podle Cruma (1991, s. 92) v devadesátých letech minulého století diskusi odborné veřejnosti v Nizozemsku jasně dominovalo kriticko-konstruktivní pojetí (srov. Crum, 1991, 1993). V realizované formě kurikula však převládalo pojetí učení pohybem a sportovní pojetí. Zároveň Crum (1991, s. 92) zaznamenal vzrůstající vliv ostatních pojetí na realizované kurikulum. Můžeme tedy říci, že nálada byla $v$ této době jasně nakloněna směřování kurikula ke kriticko-konstruktivnímu pojetí a dle naší analýzy usuzujeme, že si tento směr drží i nadále ${ }^{24}$. Pokud bychom na pojetí TV nahlíželi Naulovou (2003) optikou, označili bychom pojetí TV v Nizozemsku jako pohybové, a to jak z hlediska cílů, tak z hlediska vzdělávacího obsahu, potažmo standardů (mezicílů).

Jak uvádíme výše, ačkoliv je volnost ve volbě konkrétního učiva v Nizozemsku vyšší než u nás, pro oba státy platí, že je relativně vysoká. V Nizozemsku je vyvážena Základním dokumentem, který je velmi podrobný a návodný. Jeho obsah i struktura umožňují velmi rychle naplánovat adekvátní hodinu $T V$, která bude odpovídat jak závaznému vzdělávacímu obsahu, tak celkovému pojetí TV v Nizozemsku ${ }^{25}$. Podobný metodický materiál, který by poskytoval širší metodickou podporu a konkrétní návody pro uchopení nabízených činností, v České republice chybí. Poukazujeme proto na potřebu vzniku použitelného metodického materiálu, který by učitelé mohli využít ve své praxi. Protože ale cíle a vzdělávací obsah v českých dokumentech nejsou ve vzájemné kongruenci, měla by vzniku tohoto materiálu předcházet širší debata o obecných cílech TV v akademickém diskurzu a v př́padě revize pojetí a cílů TV by měly být rovněž reflektovány názory a preference veřejnosti.

\section{Literatura}

Buhren, C. (2004). Schulqualitätsentwicklung - Referenzpunkte für den Schulsport? In Qualitätsentwicklung im Schulsport, 3. Europäisches Schulsportforum. Retrieved from http://eads.de/cms/upload/downloads/schriften/akademieschrift24s.1-192.pdf

Crum, B. (1991). Competing orientations for PE curriculum development: the trend towards a consensus in the Netherlands and an international comparison. In: T. Williams, L. Almond \& A. Sparks (Eds.), Sport and physical activity: Moving towards excellence (s. 85-93). London: E \& FN Spon.

Crum, B. (1993). A critical review of competing physical education concepts. In J. Mester (Ed.), Current and future perspectives (s. 516-533). Aachen: Meyer \& Meyer.

${ }^{23}$ Friedrich Nietzsche kdysi prohlásil, že $k$ do ví proč, dokáže jakékoliv jak. Český dokument sice nabízí proč (vzdělávací cíle) i jak (učivo), nicméně tyto dvě části dokumentu nejsou kongruentní, proto nemohou fungovat. Standardy jsou pak navíc vázány na očekávané výstupy, takže rovněž neodrážejí cíle. Je to, jako by cílem bylo „naučit žáky sestrojit letadlo, učivem konstrukce automobilů a standardem dovednost žáků zkonstruovat vozidlo,“ což ale není cílem.

${ }^{24}$ Základni dokument se např. jasně vyhraňuje vưči biologickému pojetí TV tvrzením, že pokud by učivo (tedy 12 učebních linií) mělo splňovat cíle této koncepce, musely by být učební linie jinak strukturovány (SLO, 2011, s. 11).

${ }^{25}$ „Cílem je postavit letadlo, učivem velmi jednoduchý nákres konstrukce letadel a standardem funkční letadlo. Kdo však chce (anebo potřebuje), pro toho nizozemské kurikulum nabízí podrobný návod včetně nákresů a schémat.“ 
The content analysis of Dutch PE projected curricula from perspective of chosen curricula factors of quality: comparison with Czech PE projected curricula

Dvořák, D., Starý, K., \& Urbánek, P. (2015). Malá škola po pěti letech: proměny školy v době reformy. Pedagogická orientace, 25(1), 9-31.

Egger, K., Kühnis, J. B., Nussbaum, P., \& von Däniken, P. (2002). Qualität des Sportunterrichts: Projektbericht. Bern: Schriftenreihe des Instituts für Sport und Sportwissenschaft der Universität Bern.

Eurydice (2013). Tělesná výchova a sport ve školách v Evropě. Retrieved from https://8e6083c5e5b47fbfcf90c1b6bab6fa03dfd2cc1a.googledrive.com/host/0B3x8X77RaMBPdGxkNEc0SHZBc00/CS/EC3113672CSN_002.pdf

Eurydice. (2014). Special Eurobarometr 412: Sport and Physical Activity. Retrieved from http://ec.europa.eu/public_opinion/ archives/ebs/ebs_412_en.pdf

Eurydice (2015). Overview Netherlands. Eurydice. Retrieved from https://webgate.ec.europa.eu/fpfis/mwikis/eurydice/ index.php/Netherlands:Redirect

Gavora, P. (2010). Úvod do pedagogického výzkumu. Brno: Paido.

Habrdlová, M. (2013). Projektované kurikulum tělesné výchovy pro primární vzdělávání v Irsku: diplomová práce. Brno: Masarykova univerzita.

Hendl, J. (2005). Kvalitativní výzkum: základní metody a aplikace. Praha: Portál.

Holmes, B. (1981). Comparative education: Some consideration of method. London: Unwin Hyman.

Holmes, B. (1991). Comparative Education Methodology and Physical Education. In Standeven, J., Hardman, K. \& Fisher, D. (Eds.), Sport for all: Into the 90s (s. 19-32). Aachen: Meyer \& Meyer.

Hrubý, D. (2011). Kurikulární reforma přišla pozdě. Pedagogická orientace, 21(4), 474-480.

Janík, T., Knecht, P., Najvar, P., Doskočilová, M., Ducháčková, G., Janko, T., Zlatníček, P. (2010). Nástroje pro monitoring a evaluaci kvality výuky a kurikula. Brno: Paido.

Janík, T., Knecht, P., \& Kubiatko, M. (2011). Kvalita školy a kurikula: od expertního šetření ke standardu kvality. Praha:Výzkumný ústav pedagogický.

Janík, T., Maňák, J., Knecht, P, \& Němec, J. (2010b). Proměny kurikula současné české školy: vize a realita. Orbis scholae, 4(3), 9-35.

Janík, T., Slavík, J., Mužík, V., Trna, J., Janko, T., Lokajíčková, V., Zlatníček, P. (2013). Kvalita (ve) vzdělávání: obsahově zaměřený prístup ke zkoumání a zlepšování výuky. Brno: Masarykova univerzita.

Kuhn, J. (2011). Kurikulární reforma v poločase. Pedagogická orientace, 21(4), 480-486.

Liu, B. (2008). Zeitgenössische deutsche und chinesische Sportpädagogik im Vergleich: Ausgewählte Beispiele. (Dissertation Theses, Deutsche Sporthochschule Köln, Köln, Germany). Retrieved from http://drum.lib.umd.edu/bitstream/handle/1903/13278/Liu_umd_0117E_13491.pdf;jsessionid=C4102558DB925E3CEDAC6FAE3DA11290? sequence=1

Lupač, M. (2013). Východiska pro tvorbu výzkumného nástroje pro komparativní výzkum kurikulárních dokumentů tělesné výchovy. In T. Janík \& K. Pešková, et al., Školní vzdělávání: od podmínek k výsledkům (s. 47-58). Brno: Masarykova univerzita.

Lupač, M. (2014). Kategoriální systém jako nástroj pro komparaci kurikulárních dokumentů tělesné výchovy. In K. Pešková. Kurikulum základní školy: metodologické prístupy a empirická zjištění (s. 13-23). Brno: Masarykova univerzita.

Missler, R., \& Groenveld, R. (2014). Key Figures 2009-2013: Education, Culture and Science. The Hague: Dutch Ministry od Education, Culture and Science.

MŠMT. (2013). Rámcový vzdělávací program pro základní vzdělávání. Praha: Ministerstvo školství, mládeže a tělovýchovy.

Naul, R. (2003). Koncepce školní tělesné výchovy v Evropě. Česká kinantropologie, 7(1), 39-53.

Pühse, U., \& Gerber, M. (Eds.). (2005). International Comparation of Physical Education. New York: Mayer \& Mayer.

Richter, CH. (2006). Konzepte für den Schulsport in Europa: Bewegung, Sport und Gesundheit. Aachen: Meyer \& Meyer.

Schiro, M. (2008). Curriculum Theory: Conflicting Visions and Enduring Concerns. Los Angeles: Sage.

SLO. (2006). Kerndoelen Primair Onderwijs. Den Haag: Delta Hage. Retrieved from http://www.slo.nl/primair/kerndoelen/ Kerndoelenboekje.pdf/download

SLO. (2011). Basisdocument Bewegingsonderwijs voor het Basisonderwijs. Den Haag: Delta Hage.

Stake, R. E. (1972). Verschienede Aspekte pädagogischer Evaluation. In Wulf, Ch., Evaluation. Beschreibung und Bewertung von Unterricht, Curricula und Schulversuchen (pp. 92-112). München: R. Piper \& Co. Verlag. Retrieved from http://www. pedocs.de/volltexte/2009/1513/pdf/evaluation_D_A.pdf

Strauss, A., \& Corbinová, J. (1999). Základy kvalitativního výzkumu: Postupy a techniky metody zakotvené teorie. Brno: Albert.

Švařiček, R., \& Šed'ová, K., et al. (2007). Kvalitativní výzkum v pedagogických vědách. Praha: Portál.

Váňová, M. (1998). Teoretické a metodologické otázky srovnávací pedagogiky. Praha: Pedagogická fakulta UK v Praze.

Vlček, P. (2009). Komparativní kinantropologie. Česká kinantropologie, 13(1), 82-95.

Vlček, P., \& Janík, T. (2010). Školské reformy a tvorba kurikula tělesné výchovy v České republice, Spolkové republice Německo a Spojených státech amerických: Pedagogický výzkum v teorii a praxi. Brno: Paido.

Vlček, P., \& Mužík, V. (2012). Soulad mezi projektovaným a realizovaným kurikulem jako faktor kvality vzdělávání v tělesné výchově. Česká kinantropologie, 16(1), 31-45.

Vlček, P. (2015). Srovnávací výzkum v pedagogice: některé úvahy o metodologii problémového přístupu. Pedagogická orientace, $25(3), 394-412$. 
Vlček, P. (2016). Comparative physical education - some methodological considerations from social sciences perspective. Sborník z 10. mezinárodní kinantropologické konference ( $v$ tisku).

Vollstädt, W., Tillmann, K. J., Rauin, U., Höhmann, K., \& Tebrügge, A. (1999). Lehrpläne im Schulalltag. Eine empirische Studie zur Akzeptanz und Wirkung von Lehrplänen in der Sekundarstufe I. Opladen: Leske + Budrich.

Wooning, Ch. (2004). The Education System in the Netherlands 2003. Dutch Eurydice Unit, Netherlands Ministry of Education, Culture and Science. Retrieved from http://www.ibe.unesco.org/National_Reports/ICE_2004/netherlands.pdf 